\title{
Contradictions in the Treatment of Roma and Sinti During the Holocaust
}

\author{
Katherine Price is a junior majoring in History and minoring in French and Education. She is
} from Lawrence. This article was completed for History 341: Hitler and Nazi Germany.

\begin{abstract}
:
In this article, I argue that the Nazi treatment of Roma and Sinti Gypsies was distinct from the treatment of other victim groups by virtue of its inconsistency. There was never a clear articulation of the ideological position of the Nazis regarding the Roma, and the guidelines that were in place were applied haphazardly. A wide variety of exemptions theoretically protected Roma from arrest and deportation. As distinct from the Nazi beliefs about Jews, so-called "racially pure Gypsies" were sometimes considered more valuable and were protected. These rules, however, were never consistently followed. The extent to which the Roma were persecuted by the Nazis was often determined more by the attitudes and personal beliefs of regional administrators, combined with the perceived demands of the local situation, than by an intentional Nazi mandate.
\end{abstract}

$\mathrm{I}^{\mathrm{n}}$ $n$ the decades of research and commemoration that followed the Holocaust, the Nazi persecution of Roma has often been overlooked. Frequently called "Gypsies," the Roma and Sinti ethnic groups emigrated to Europe from India in the thirteenth or fourteenth century. ${ }^{1}$ Although they experienced discrimination from the time of their arrival, the violence increased dramatically during the Nazi regime. Like the Jewish community, the Roma suffered exclusion, sterilization, deportation, and mass murder. To gain a more comprehensive understanding of the Holocaust, their experience bears investigating. In the absence of clearly articulated doctrines, the treatment of the Roma was determined by the negotiation between official Nazi policy and local sentiments, resulting in a spectrum of experiences.

The Roma and Sinti people have faced discrimination since their arrival in Europe.

${ }^{1}$ The term "Gypsy" is now considered to be pejorative. Since most members of this ethnic group refer to themselves as Rom (plural Roma), this term will be used exclusively hereafter, except when historical accuracy necessitates the use of the term "Gypsy."
Local populations tended to be suspicious of traditional Romani practices, such as nomadism, and commonly believed that all Roma were thieves, kidnappers, and murderers. Additionally, the Roma were accused of refusing to assimilate to their host cultures. In reality, integration was frequently impossible, due to laws circumscribing Roma status and prohibiting their ownership of land, making itinerancy the only way of life possible. When the Nazis took power in the early twentieth century, many discriminatory laws were already in place. The policies they created for the Roma were not entirely unprecedented, but they were far more extreme.

A few recent works have examined the policies that guided Nazi treatment of Roma. Historians have attempted to determine if Nazi leadership was intentionally pursuing the eradication of the Roma ethnic group, as they were the Jews, or if the volatile climate created by the Nazis only incidentally led to violence against Roma. Each study comes to different conclusions. 
In their book, Gypsies Under the Swasti$k a$, Donald Kenrick and Grattan Puxon make the argument that Nazi policy towards the Roma was intentionally genocidal from the beginning and just as murderous as policies targeting Jews. They admit that the policies governing the Roma were often haphazardly applied but argue that Jewish racial laws were also inconsistent. They mainly approach the Holocaust from an intentionalist, rather than functionalist, perspective, suggesting that the end result for both Jews and Roma - mass murder and destructionwas the goal from the beginning, rather than evolving over time.

By contrast, Guenter Lewy argues that Heinrich Himmler always intended to have Roma policies that were distinct from Jewish ones. While Roma who were not deported were still subject to many legal restrictions, including forced sterilization, he dismisses the idea that their fate is comparable to that of the Jews. In his opinion, the Roma's higher rate of survival can be directly attributed to Himmler's fascination with them.

Michael Zimmermann approaches the persecution of the Roma from a functionalist position, suggesting that mass murder and violence against Roma was not planned from the beginning, but developed organically. He argues that there was no consensus regarding the Roma among Nazi authorities, demonstrating that central and local governments often acted in contradiction to each other. According to Zimmermann, it was this tension between the central government and the local administrators, rather than the impact of decisions made by Himmler or other executives, that escalated the violence against Roma and ultimately led to their murder.

Each of these studies approaches the violence against the Roma from a different perspective, whether arguing that Nazi policies were murderous from the beginning or that they were never intentionally murderous at all. I argue that there was always ambiguity in the official policies governing the treatment of Roma, but that the beliefs of Himmler and other top authorities did influence the actions of local administrators. If local authorities were sometimes guided by government or party directives, however, they just as often followed their own beliefs or the perceived needs of their particular context. The Roma experience of the Holocaust can only be understood as a spectrum, because no consistent rule was applied to them during the Third Reich.

The Nazis viewed the Roma as inferior, but there was a lack of consensus as to their exact position in the constructed racial hierarchy. They were generally believed to be "work-shy," uneducable, unhygienic, inevitably criminal, mentally deficient, and generally "a-social.". The treatment that they merited, based on those characteristics, was less clear. There was a spectrum of beliefs about the best solution to "the Gypsy question." ${ }^{3}$ Hitler, who was closely involved in the formation of the policies towards Jews, was uninterested in the Roma and only mentioned them twice during his

\footnotetext{
${ }^{2}$ Donald Kenrick and Grattan Puxon, Gypsies Under the Swastika (Hatfield: University of Hertfordshire Press, 2009), 12.

3 "Circular on the Fight Against the Gypsy Nuisance Issued by Himmler," Jewish Virtual Library, accessed November 24, 2019, https://www.jewishvirtuallibrary.org/circular-on-the-fight-against-the-gypsy-nuisance-issued-by-himmler.
} 
time as chancellor, though SS officer Perry Broad insisted that it was "Hitler's aim to wipe out all Gypsies." By contrast, Heinrich Himmler, a leader of the Schutzstaffel (SS), was obsessed with the Roma. In comparison to some Nazi leaders, he held a more positive belief on the value of the Roma race. Based on the work of Dr. Robert Ritter, head of the Race Hygiene and Population Biology Research Center of the National Health Office, Himmler believed that there was a kind of kinship between the Aryan race and some of the Roma, because of the latter's Indian origins. Though Ritter did not believe any of the Roma were equal to Aryans, he argued that it was the "part-Gypsies," rather than "full-Gypsies," who posed the greatest danger to the German population and that the Roma with more "pure" blood might be worth preserving. ${ }^{5}$ In his 1938 circular on "Combatting the Gypsy Nuisance," Himmler emphasized the importance of distinguishing between "pure and part-Gypsies," and stated that "experience shows" part-Gypsies were more likely to be involved in crime. ${ }^{6}$ "Pure Gypsies," according to Himmler, were also less likely to intermarry with Germans and thus did not pose a danger to German blood. "Part-Gypsies" could possibly be accepted into German society if they were

${ }^{4}$ Guenter Lewy, "Himmler and the 'Racially Pure Gypsies, " Journal of Contemporary History 34, no. 2 (April 1999): 202; Kenrick and Puxon, Gypsies Under the Swastika, 131.

${ }^{5}$ Ibid, 203.

6 "Circular on the Fight Against the Gypsy Nuisance Issued by Himmler," Jewish Virtual Library, accessed November 24, 2019, https://www.jewishvirtuallibrary.org/circular-on-the-fight-against-the-gypsy-nuisance-issued-by-himmler.

${ }^{7}$ Kenrick and Puxon, Gypsies Under the Swastika, 36. fully assimilated and had been sterilized. ${ }^{8}$ Thus, as opposed to Jews, Himmler believed that full-blooded Roma could potentially have a future in the German Reich, though mischlinge Roma - at least those considered "asocial" because of alleged crimes, "non-German" customs, and itinerancycould not. Ritter suggested designating a territory within which the "racially pure" Roma could wander, separate from the German people but allowed to maintain their own customs. ${ }^{9}$ Himmler seems to have supported this suggestion, writing vaguely that the goal of legislation regarding Roma was "the regulation of [their] way of life," not their sterilization or extermination. ${ }^{10}$ Eva Justin, however, a racial researcher who worked with Ritter, disagreed with the assumption that the purer elements in the Roma population were superior. She declared that "Gypsies and part-Gypsies of predominantly Gypsy blood, whether socially assimilated or asocial and criminal, should as a general rule be sterilized," though she allowed that "socially integrated" Roma with "less than half Gypsy blood" could be accepted into the German population. ${ }^{11}$ According to Justin, any degree of Roma blood merited exclusion, and a greater degree meant a larger measure of negative Roma characteristics. Another researcher, Dr. Behrendt,

\footnotetext{
${ }^{8}$ Michael Zimmermann, "The National Socialist Solution of the Gypsy Question: Central Decisions, Local Initiatives, and Their Interrelation," Holocaust and Genocide Studies 15, no. 3 (Winter 2001): 420.

${ }^{9}$ Ibid, 16.

10 "Circular on the Fight Against the Gypsy Nuisance Issued by Himmler," Jewish Virtual Library, accessed November 24, 2019, https:/www.jewishvirtuallibrary.org/circular-on-the-fight-against-the-gypsy-nuisance-issued-by-himmler.

${ }^{11}$ Kenrick and Puxon, Gypsies Under the Swastika, 19.
} 
agreed, declaring that "All Gypsies should be treated as hereditarily sick" and imprisoned and sterilized. ${ }^{12}$ Himmler and Ritter, by contrast, argued it was mainly the mixed blood Roma who were "asocial and useless." ${ }^{13}$ Though no researchers or authorities in the Third Reich believed Roma were equal to Germans, there was no consensus about their place in the racial world.

Because there was no consistent belief about the value and nature of the Roma, Nazi policies were left largely to the interpretation of local authorities. Though there were some official criteria regarding which Roma were supposed to be deported to concentration camps and which were not, it was applied or ignored on the basis of the opinion of local officials. According to Himmler's stated policy, certain "pure" Roma-exclusively drawn from the Sinti and Lalleri tribes-were to be exempted from deportation. However, the measures by which Roma were deemed either "pure" or mischlinge were extremely arbitrary and sometimes contradictory. Settled Roma, for instance, were more likely to be exempted from deportation, although this indicates they were more integrated into German society, which completely contradicts the purpose of the exemption from Himmler's perspective. ${ }^{14}$ In the small town of Breitscheid, the criminal police determined three families were "racially pure," but under pressure from the mayor they were deported anyway. ${ }^{15}$ Additional exemptions were granted for Roma who were married to Ger-

\footnotetext{
${ }^{12}$ Ibid, 14.

${ }^{13}$ Ibid, 16.

${ }^{14}$ Ibid, 39.

${ }^{15}$ Guenter Lewy, Nazi Persecution of the Gypsies (Cary: Oxford University Press, 1999): 266.
}

mans, who were "socially adjusted," or who had foreign citizenship. ${ }^{16}$ Roma who were in military service, veterans who had been wounded, and their families were also exempted. ${ }^{17}$ Except for "racially pure" Roma, all those exempted from deportation were expected to submit to sterilization. ${ }^{18}$

Exemption categories that existed on paper had little bearing on the actual deportation of the Roma. In an oral testimony, Karl Stojka, a Roma who was deported to Auschwitz, reported that his sister had a steady job and thus should have been exempted on the basis of being "socially adjusted." After missing one day of work due to sickness, she was declared "work-shy" and arrested. ${ }^{19}$ The father and brother of Josef Reinhardt, another Roma survivor, had both served in World War I and were patriotic Germans; his brother had even been wounded. Both were sent with their families to Auschwitz. ${ }^{20}$ In other communities, Roma were given greater freedom than was circumscribed within official decrees, sometimes being granted special travelling permits so they could continue to itinerate. ${ }^{21}$ Outside of Germany, in the countries under Nazi control, Roma deportations appear to have been even more arbitrary. No attempt was made to distinguish between pure and mischlinge Roma outside of Germany, indicating that distinctions which

\footnotetext{
${ }^{16} \mathrm{Ibid}, 261$.

${ }^{17}$ Ibid.

${ }^{18} \mathrm{Ibid}, 262$.

${ }^{19}$ Karl Stojka, "Oral History," interviewed by Linda

G. Kuzmack, United States Holocaust Memorial Museum, April 29, 1992, https://collections.ushmm. org/search/catalog/irn504716.

${ }^{20}$ State Museum of Auschwitz-Birkenau, Memorial Book: The Gypsies at Auschwitz-Birkenau (New York, NY: Saur, 2002): 1523.

${ }^{21}$ Zimmermann, "The National Socialist Solution of the Gypsy Question," 417.
} 
were vitally important to Himmler failed to be extended throughout the Nazi belief system. ${ }^{22}$ Karl Stojka describes the arrival of socalled "Gypsies" who were blond, spoke no Romani, and were deported on the basis of a great-great-grandfather who was a tinker, a traditional Roma occupation. ${ }^{23}$ Without clear dictates from Berlin, community officials had great license to apply policies as they saw fit, based on "racist improvisation and random notions." 24

Even within the walls of concentration camps, the actions of Nazi officials revealed the ambiguity surrounding Roma status. In Auschwitz, Roma families were not separated on the platform, as was the case for almost all other inmates. ${ }^{25}$ Instead, they were taken to a group of barracks known as the Gypsy Family Camp. At first, most of the Roma were not detailed for forced labor, either ${ }^{26}$ The conditions of the barracks were still as inhumane and abominable as the rest of the camp, however. Karl Stojka describes the rampant disease and the rapid death of the inmates, especially children. ${ }^{27}$ Of the estimated 360 babies who were born in the camp, all died, and only three lived more than nine months. ${ }^{28}$ The vast majority of Roma in Auschwitz died due to the living conditions or from treatment meted out by camp officials, not through an extermination policy dictated by Berlin; of the more

\footnotetext{
${ }^{22}$ Kenrick and Puxon, Gypsies Under the Swastika, 36.

${ }^{23}$ Stojka, interview.

${ }^{24}$ Zimmerman, "The National Socialist Solution of the Gypsy Question," 420.

${ }^{25}$ Lewy, Nazi Persecution of the Gypsies, 279.

26 Ibid, 282.

${ }^{27}$ Stojka, interview.

${ }^{28}$ State Museum of Auschwitz-Birkenau, Memorial Book, 1481-1489; Kenrick and Puxon, Gypsies Under the Swastika, 139.
}

than 19,000 Roma who died in Auschwitz, only about 5,000-6,000 were killed in the gas chambers. ${ }^{29}$ Revealing the uncertainty surrounding the place of the Roma in Nazi beliefs, Rudolf Höss, one of the camp administrators, expressed concern over the conditions of the barracks, declaring that they were "utterly unsuitable" for a family camp. He even requested special rations for children and pregnant women. ${ }^{30}$ In his testimony, Karl Stojka confirms this, stating that small children received jam with their bread. ${ }^{31}$ Although these rations were soon stopped, the fact that the request was submitted and granted, at least at first, demonstrates that Nazi policy regarding the Roma was flexible enough to be variously adapted by lower officials to be more brutal or more humane depending on their own beliefs. Roma survivor Hermine Horvath describes a member of the SS who was "so touched" by the malnourished Roma children in Auschwitz that he procured some extra bread for them. ${ }^{32}$ For an unknown reason, the man was gone the following day - perhaps due to the disapproval of his superiors. ${ }^{33}$ In Horvath's same paragraph, however, she writes that "the point" of the camps was "to break us Gypsies down to nothing. ${ }^{" 34}$ Her experience unites both the ambivalence of Nazi ideology towards Roma, which allowed a member of the SS to be moved by compassion towards Roma where perhaps he had hardened

\footnotetext{
${ }^{29}$ Zimmerman, "The National Socialist Solution of the Gypsy Question," 420.

${ }^{30}$ State Museum of Auschwitz-Birkenau, Memorial Book, 1663.

${ }^{31}$ Stojka, interview.

32 State Museum of Auschwitz-Birkenau, Memorial Book, 1510.

${ }^{33} \mathrm{Ibid}$.

${ }^{34}$ Ibid.
} 
his heart towards Jews, and the brutality of the camp authorities towards all inmates, where the default was violence where policies were yet uncertain. In other camps, Roma received no special treatment, though in Ravensbrück children were sometimes allowed to remain with a parent. ${ }^{35}$ Some Roma were also exterminated on arrival in Auschwitz and other killing centers. ${ }^{36}$ Across camps, Roma received treatment consonant with the varying opinions of their racial status.

Additionally, local authorities often based their treatment of Roma on situational needs, not on ideological argument. On the night of August 2, 1944, the Gypsy Family Camp at Auschwitz was liquidated. ${ }^{37}$ After maintaining the camp for sixteen months, the decision to suddenly transport 3,500 Roma to forced labor in other camps and to murder nearly 3,000 more seems incongruous. ${ }^{38}$ The inconsistency may be explained by the transports of Hungarian Jews that arrived immediately after the murder of the Roma and were installed in formerly Roma-occupied barracks. ${ }^{39}$ It seems that the liquidation of the Gypsy Family Camp was less a function of ideology than it was of necessity. Previous to this moment, it appears it was convenient to keep the Roma alive. Even this decision may have based on the usefulness of the Roma in medical experimentation in Auschwitz, rather than some humanitarian instinct. Dr. Mengele used the Roma extensively in his research, espe-

\footnotetext{
${ }^{35}$ Kenrick and Puxon, Gypsies Under the Swastika, 127.

${ }^{36}$ Ibid, 143; Lewy, Nazi Persecution of the Gypsies 296.

${ }^{37}$ Ibid, 299.

${ }^{38}$ Ibid, 296-299.

${ }^{39}$ Ibid, 300.
}

cially twins ${ }^{40}$ There is some evidence that he ensured better treatment for some of his subjects, establishing a kind of kindergarten for Roma children and bringing them extra rations and even toys. ${ }^{41}$ The same Roma children, however, were later killed and dissected under his direction. ${ }^{42}$ Dr. Mengele was interested in keeping the Roma alive and even healthy, but only because they suited his needs. Whatever beliefs the Nazis had about the Roma were subsumed to the convenience of the moment.

Despite additional legislation attempting to clarify their position, Nazi beliefs and policy regarding Roma remained contradictory and inconsistent, leading to varying application by different officials. As late as 1944, when thousands of Roma had been arrested and killed, Himmler wrote that certain laws had erroneously led to identical treatment of Jews and Roma, but that this result "does not correspond with the differentiated political position to be granted to these groups. ${ }^{~} 43$ His insistence on the different status of Roma is evidence that other officials disagreed, or at least acted as if they did. Sometimes the Roma were kept separate from other inmates; Jewish survivor Gina Beckerman risked being shot for interacting with a Roma girl in Auschwitz. ${ }^{44}$ But in other camps, Jews and Roma were imprisoned together and were treated no differently. Dutch political prisoner Anthony Van

\footnotetext{
${ }^{40}$ Kenrick and Puxon, Gypsies Under the Swastika, 146; Lewy, Nazi Persecution of the Gypsies, 290.

${ }^{41}$ Lewy, Nazi Persecution of the Gypsies, 292.

${ }^{42}$ Ibid, 294.

${ }^{43}$ Lewy, Nazi Persecution of the Gypsies, 357.

${ }^{44}$ Gina Schweitzer Beckerman, "Oral history," interviewed by Randy M. Goldman, United States Holocaust Memorial Museum, July 13, 1994, https:// collections.ushmm.org/search/catalog/irn504753.
} 
Velsen lived in the Roma section of Auschwitz for a time and described the Roma as being treated "in the same manner as the Jews." ${ }^{45}$ In much of Germany and German-occupied lands, Himmler's edicts had little effect on the daily experience of the Roma.

Analyzing the way Nazi beliefs imposed from above, often contradictory in and of themselves, intersected with the varying sentiments and needs of local administrators speaks more broadly about the crimes perpetrated by the Nazis. Ideology could be

${ }^{45}$ Anthony F. Van Velsen, "Oral history," interviewed by Dr. Yaffa Eliach, United States Holocaust Memorial Museum, October 27, 1981, https://collections. ushmm.org/search/catalog/irn513328; Kenrick and Puxon, Gypsies Under the Swastika, 77. the driving factor in the actions of military commanders and SS men, and perhaps for the Jews, the Aryan's "anti-race," it usually was. ${ }^{46}$ Just as often, however, the local situation or their own feelings dictated their actions. For the Roma, this resulted in a kaleidoscope of experiences, because there was no one Nazi rule for their treatment. Thus, a full understanding of the Holocaust necessitates recognizing the spectrum of experiences, as simply citing the number of deaths "does not represent the full measure of suffering of the Romanies and Sinti." 47

\footnotetext{
${ }^{46}$ Zimmermann, "The National Socialist Solution of the Gypsy Question,” 415.

${ }^{47}$ Kenrick and Puxon, Gypsies Under the Swastika, 153.
} 


\section{Bibliography}

Beckerman, Gina Schweitzer. “Oral history.” Interviewed by Randy M. Goldman. United States Holocaust Memorial Museum, July 13, 1994. https://collections.ushmm.org/search/catalog/ irn504753

"Circular on the Fight Against the Gypsy Nuisance Issued by Himmler." Jewish Virtual Library. https://www.jewishvirtuallibrary.org/circular-on-the-fight-against-the-gypsy-nuisanceissued-by-himmler.

Kenrick, Donald and Puxon, Grattan. Gypsies under the Swastika. Hatfield: University of Hertfordshire Press, 2009.

Lewy, Guenter. Nazi Persecution of the Gypsies. Cary: Oxford University Press, 1999. ProQuest Ebook Central. https://ebookcentral.proquest.com/lib/ku/reader.action?docID=273065

Lewy, Guenter. "Himmler and the 'Racially Pure Gypsies'.” Journal of Contemporary History 34, no. 2 (April 1999): 201-214. www.jstor.org/stable/261215.

State Museum of Auschwitz-Birkenau. Memorial Book: The Gypsies at Auschwitz-Birkenau. New York, NY: Saur, 2002.

Stojka, Karl. "Oral History.” Interviewed by Linda G. Kuzmack. United States Holocaust Memorial Museum, April 29, 1992. https://collections.ushmm.org/search/catalog/irn504716.

Van Velsen, Anthony F. “Oral history.” Interviewed by Dr. Yaffa Eliach. United States Holocaust Memorial Museum, October 27, 1981. https://collections.ushmm.org/search/catalog/ irn513328.

Zimmermann, Michael. "The National Socialist Solution of the Gypsy Question: Central Decisions, Local Initiatives, and Their Interrelation." Holocaust and Genocide Studies 15, no. 3 (Winter 2001): 412-427. 